\title{
Integration of Recycled Industrial Wastes into Pavement Design and Construction for a Sustainable Future
}

\author{
Ashish T. Asutosh ${ }^{1} \&$ Nawari O. Nawari ${ }^{2}$ \\ ${ }^{1}$ Graduate student, College of Design, Construction, and Planning, University of Florida, USA \\ ${ }^{2}$ Associate Professor, School of Architecture, College of Design, Construction, and Planning, University of Florida, \\ USA \\ Correspondence: Ashish T. Asutosh, Graduate student, College of Design, Construction, and Planning, University \\ of Florida, USA. E-mail: asishasutosh@ufl.edu
}

Received: September 10, 2016 Accepted: October 11, 2016 Online Published: February 3, 2017

doi:10.5539/jsd.v10n1p9 URL: http://dx.doi.org/10.5539/jsd.v10n1p9

\begin{abstract}
Transportation Infrastructure has remained a key element for the economic and social development. Especially in developing countries, the demand for new roads and maintenance of existing roads is very high as they depend on the overall economic development. These calls for transforming the methods the roads are being constructed. Recent studies have shed light on the concept of making transportation system greener and more sustainable, which can be a fast track to achievie the goals of saving the planet from further generations. One of the effective ways of addressing this issue is by substituting or replacing pavements layers by sustainable alternate materials. Promising alternate materials have been investigated in road construction-specifically using recycled wastes. The purpose of this study is to analyze the environmental significances of alternate materials such as recycled tires, recycled glass and waste plastics in road construction and delineate their economic and environmental importance. This is addressed by comparing various parameters such as global warming potential, carbon footprint, cost, and other environmental impact factors. The results of this investigation showed that the use of these materials in pavement construction has substantial environmental and economic benefits. These results will assist in developing revised pavement design and construction methods that are more efficient and economically feasible.
\end{abstract}

Keywords: industrial wastes, carbon footprint, climate change, recycled industrial wastes, roads design, and sustainable transportation systems

\section{Introduction}

With seven billion people on the planet and another one billion expected, mankind and other living organisms are suffering from a man-made disaster known as global climate change. The need for taking strong actions has never been more serious analyzing at the damages to the environment. Sustainable development is the development that meets the needs of the present without compromising the ability of future generations to meet their essential needs.(The Brundtland Commission, Oxford University Press, 1987)

Excessive burning of fossil fuel and natural resources has brought us to a position where the planet is under maximum stress. This is the reason why sustainable development practices are at the pinnacle of our responsibilities. The topic of sustainable development is a concept which encompasses many factors such as sustaining biodiversity, social sustainability, climate change mitigation and other factors. The major contributor to this issue is our built environment. This is where we spend the maximum amount of resources and fossil fuels resulting in excess carbon emissions and carbon footprint. The built environment consists of all the structures ranging from buildings, roads, bridges, and all other man-made entities which support human civilization.

Progress has been made in many sectors to embed sustainability in our daily lives but still has miles to go achieving the desired balance between nature and human. As per the Millennium Development Goals, the focus on sustaining health, wealth, better economy and better-living conditions of people are at priority. This study will be an attempt to solve one of the development goals which focuses on the built environment where transportation infrastructure is one of its major components. 


\section{Statement of the Problem}

Transportation Infrastructure has remained a key element in the economic and social development. It impacts trade, production, consumption, health and other factors. Planning, design, construction of roads has been nascent towards implementing sustainable methods. The road network requires massive amounts of energy to construct and the materials used are highly unsustainable in nature. The core material such as asphalt or bitumen in road construction is produced through fractional distillation involves burning of crude oil which is highly toxic to the environment. This sector produces the highest level of greenhouse gas directly through fossil energy used in mining, transportation, paving works, and indirectly through the emissions from vehicles. Indeed, the constant increase in the number of vehicles which leads to more traffic. This generates a substantial increase in pollution and noise disturbances (World Highways, 2015).

There is a requirement for an immediate change in transforming the methods in which the roads are being laid. Recent studies have shown that making our transportation system greener and sustainable, can be a fast track to achieving the goals of saving the planet from further critical conditions. Therefore, we should start and encourage examining and formulating techniques and strategies to design and construct sustainable road infrastructures. This study takes a step forward into investigating the alternatives of the process and analyze the reasons and factors that influence the application of sustainable materials in road construction.

\section{Backround}

\subsection{Sustainability Concepts and Material Considerations}

A report by the US federal highway administration in 2015 unfolded the requirement of sustainability in road sectors. Sustainability is a continuous effort where the conventional practices are changed and refined to meet the current goals. This referred to solving issues such as greenhouse gas (GHG) emissions, energy consumption, impacts on habitat, water quality, changes in the hydrologic cycle, air quality, mobility, access, freight, community, depletion of non-renewable resources, and economic development. Along with the urgent need to fight climate change and global warming, economics has proved to be of benefit in the long term to any organization which decides to integrate sustainability into their businesses. (World Green Building Trend, 2016).The materials used in the road are basically extracted from the surrounding and modified to meet the necessary engineering requirements. For road sustainability, these are keen components and relevant factors that should be investigated when designing roads. These include lifecycle cycle analysis, carbon footprint. Life cycle analysis (LCA) is a systematic approach of looking at a product's complete life cycle, from raw materials to final disposal of the product. It offers a cradle to grave approach to a product or process considering environmental aspects and potential impacts (Williams 2009). It is one of the best methods to analyze the amount of energy spent throughout its lifecycle. Carbon footprint is the total amount of greenhouse gasses produced to directly and indirectly support human activities, usually expressed in equivalent tons of carbon dioxide $\left(\mathrm{CO}_{2}\right)$ in a given time frame.(timeforchange, 2016)This refers to fossil fuel -consumption from the point of extraction to the place where the product is at any particular date. The use of alternate materials and recycled components must be an important decision to reach the sustainability goals in road infrastructure.

\subsection{Durable and Sustainable Road Construction}

The proposed solutions for the construction of sustainable roads in developing countries are described by many studies.

\subsubsection{Recycled Asphalt Pavement and Use of Treated PVC}

Reclaimed asphalt pavements have been very popular where the old sections of the road are needed to be re-recycled for the construction and rehabilitation of other roads. In India, for example, researchers have concluded there is the benefit of high-quality RA in design mixes. Experiments were carried out in making mixes proportion of RAP: VA aggregates: fly ash and finding a better mix for using on road construction. Tests of different proportions of these ingredients were conducted like Optimum Moisture Content, gradation curves, Unconfined Compressive Test and California Bearing Ratio which were found to be satisfactory. (Saride, 2015). RAP and fly ash must be frequently used in large quantities for a sustainable approach to road construction. Application of waste PVC (Polyvinyl Chloride), recycled PVC (2-4mm) in size in the bitumen mix for the base course of the pavement can be a technique to reduce the use of natural materials. The treated PVC can be used to prepare two blends of bitumen mixes $3 \%$ and $5 \%$ by weight (Behl, 2014).

\subsection{Industrial Wastes as Virgin Material}

Studies show potential alternate materials which have been identified and experimented to be beneficial for roads to make resilient to the environment. These alternate materials are basically industrial waste which is toxic to the 
surrounding environment and has potential in serving similar purposes as virgin materials in other industries.

\subsubsection{Ash}

Common Industrial wastes such as Ash (Fly Ash, Bottom Ash, Pond Ash, Magnetherm Slag ) are being used in road and building construction and have gained popularity since many years. Fly ash can cause environmental degradation creating health hazards and requires large areas of landfill. Countries such as India have already formulated guidelines to use ash in road construction. It can be used in the lightweight embankment to reduce settlement. Also, ferry bumpers, composting and safety barriers have been used as additive to the pavement to increase strength and improve drainage characteristics. (IRC SP-58, 2001)

\subsubsection{Tires}

The use of scrap tires is proven efficient in building and rehabilitating roads. (David, 1992) Typical uses are wet and dry processes where the scrap tires are used as a binder in the asphalt mixture or used with aggregate mixtures respectively. Experiments were carried by Washington State Department Of Transportation such as SAM(stress absorbing membrane), SAMI(stress absorbing membrane interlayer) and other types which also proved beneficial to the concept of recycled use of scrap tires but not cost effective in that period of time. The rubber-asphalt paving material has still a potential space for improvement to use on a massive scale. (WSDOT, 1992).In addition, a distinct experimentally study verified the use of tires in taking various pavements design layers. The design sections consisted of different proportions of soil, scrap tires chips, and geotextiles which were constructed and tested in real time. It was successful in getting the desired parameters with minor challenges. (Neil, 1992).

Table 1. Engineering properties of tire bales, Encore Systems Inc. (TDOT, 2016).

\begin{tabular}{cccccc}
\hline $\begin{array}{c}\text { Chip size } \\
\text { (inches) }\end{array}$ & $\begin{array}{c}\text { Friction angle } \\
\text { (degrees) }\end{array}$ & $\begin{array}{c}\text { Cohesion } \\
\text { (psi) }\end{array}$ & Lateral earth pressure at rest(K 0) & Poisson's ratio & \multicolumn{2}{c}{ Elastic Modulus } \\
\hline 2 & 21 & 1.12 & .41 & .28 & 164 \\
3 & 19 & 1.67 & .26 & .20 & 163 \\
2 & 25 & 1.25 & .47 & .32 & 112 \\
\hline
\end{tabular}

\subsubsection{Glass}

It has been reported that asphalt does not adhere to glass surfaces as it does with aggregate. It could only be used in limited quantity up to $15 \%$ of the total aggregate volume using glass finer than $3 / 8$ inch sieve. (Ismail, 2008).To resolve the adhesion problem, few additives like hydrated lime was introduced and the results seemed promising. Many other anti-stripping agents were discovered to solve the adhesion for the glass and asphalt. This result in the use of waste glass on low volume roads with the help of binders. According to an experiment at University of Baghdad, the 28-day compressive strength value of 45.9 MPa was obtained from the concrete mix made of $20 \%$ waste glass fine aggregate, which represents an increase in the compressive strength of up to $4.23 \%$ as compared to the control mix. (Ismail, 2008).

Table 2. Compressive strength of waste glass concrete mixes (Ismail, 2008).

\begin{tabular}{ccccc}
\hline \% Waste Glass & \multicolumn{4}{c}{ Curing ages (Days) } \\
& Compressive & strength (Mpa) \\
\hline & 3 & 7 & 14 & 28 \\
0 & 26.9 & 31.5 & 43.8 & 44.0 \\
10 & 29.1 & 34.6 & 39.1 & 44.3 \\
15 & 28.9 & 32.0 & 38.3 & 42.0 \\
20 & 27.6 & 31.7 & 38.0 & 45.9 \\
\hline
\end{tabular}

The pozzolanic effect of waste glass in concrete is more obvious at the later age of 28 days. The optimum percentage of waste glass that gives the maximum values of compressive and flexural strengths is about $20 \%$ 
(Ismail, 2008).

Table 3. Fresh densities of the waste glass concrete mix (Ismail, 2008).

\begin{tabular}{lllll}
\hline$\%$ waste glass & 0 & 10 & 15 & 20 \\
\hline Fresh Density & 2467.90 & 2445.70 & 2428.30 & 2420.90 \\
\hline
\end{tabular}

A study at the Swinburne University of Technology experimented samples of recycled glass for their strength and geotechnical characteristics which delivered satisfactory results compared to being treated as materials for pavement design. Three recycled glass sample were taken and named Fine Recycled Glass (FRG), Medium Recycled Glass (MRG) and Coarse Recycled Glass (CRG). The maximum particle size of these samples was $4.75 \mathrm{~mm}, 9.5 \mathrm{~mm}$ and $19 \mathrm{~mm}$ respectively. The FRG and MRG samples were found more suitable for replacement (Disfani, 2011).

Table 4. Engineering properties of recycled glass (Disfani, 2011).

\begin{tabular}{lll}
\hline Test & Fine recycled glass & Medium recycled glass \\
\hline Specific Gravity & 2.48 & 2.5 \\
Flakiness Index & -- & 85.4 \\
Organic content $(\%)$ & 1.3 & 0.5 \\
$\mathrm{pH}$ Value & 9.9 & 10.1 \\
Standard Proctor $\left(\mathrm{kN} / \mathrm{m}^{3}\right)$ & 16.7 & 18.0 \\
Modified proctor $\left(\mathrm{kN} / \mathrm{m}^{3}\right)$ & 17.5 & 19.5 \\
LA Abrasion Value & 24.8 & 25.4 \\
\hline
\end{tabular}

Glass can not only be used in flexible pavements but also in rigid pavements. There is great potential for the utilization of waste glass in concrete pavement in several forms, including fine aggregate, coarse aggregate (Shayan, 2011). Use of fine waste glass can also act as an additive to fine aggregate which could produce promising results (Ismail, 2008).

\subsubsection{Plastics}

Polyethylene is one of a kind of polymers which was investigated for the potential to enhance asphalt mixture properties. It has been also discovered that recycled plastics can be used in the construction of bituminous or asphalt roads. The recommended proportion of the modifier is $12 \%$ by the weight of bitumen content. It was found to increase the stability, reduce the density and slightly increase the air voids and the voids of mineral aggregate. (Awwad, 2007).

The polymer in plastics and the bitumen mixture can withstand high temperatures and can resist the action of water. The sound proofing properties of plastics cause the roads to reduce noise pollution and no toxic gasses are produced (Swami, 2012). This has been practically implemented in the roads of Himachal Pradesh, India and proved to be very efficient (DNA India, 2010).However, there are many steps involved from the collection of waste plastics to finally using them in the road construction. The plastics should be recycled and prepared for usage in the mix designs. This consists of several economic and technological constraints such as the requirement of chemical modification to recover the base chemical constituents (Rebeiz, 1995).

There are many adverse properties of bitumen in reference to pavements construction which and can cause distress to the traffic. First, bitumen is the result of the burning of fossil fuels which has a negative impact environment. At high temperature, bleeding of road prevails reducing the performance of surface courses. Due to the chemical reactions for instance oxidation, bitumen may crack. Bitumen strips off from the aggregate forming pothole on roads as being water repellent material in action with water which reduces the life of roads. Plastic due to its chemical composition it acts as a good binder to bitumen. It Softens at around 260 degrees Fahrenheit and there is no effervesces of any gasses in the temperature range of 260-350 degree Fahrenheit Have a binding property to enhance their binding property (Gawande,2012). Another study from Maulana Azad National Institute of Technology experimentally proved that using wastes plastics can improve the design quality of the 
pavement as well as reduce the use of bitumen. The experiment consisted of designing a Semi Dense Bituminous Concrete (SDBC) mix which was prepared using Marshall Method of bituminous mix design. This SDBC was prepared with conventional, 60/70 grade bitumen added with varying percentages of LDPE and were studied for various parameters (see Table 5).

Table 5. Results of SDBC mix for varying percentages of LDPE (Rokade, 2012)

\begin{tabular}{|c|c|c|c|c|c|c|c|c|}
\hline $\begin{array}{l}\text { SI } \\
\text { No }\end{array}$ & $\begin{array}{c}\text { LDPE } \\
(\%)\end{array}$ & $\begin{array}{c}\text { BITUME } \\
\text { N } \\
(\%)\end{array}$ & $\begin{array}{c}\text { MARSHAL } \\
\text { STABILITY } \\
(\mathrm{Kg})\end{array}$ & $\begin{array}{c}\text { FLOW } \\
\text { VALUE } \\
(\mathbf{m m})\end{array}$ & $\begin{array}{c}\text { BULK } \\
\text { DENSITY } \\
\text { (GM/CC) }\end{array}$ & $\begin{array}{c}\text { AIR } \\
\text { VOIDS } \\
\% \\
\text { Vv }\end{array}$ & $\begin{array}{c}\text { VOIDS IN } \\
\text { MINERAL } \\
\text { AGGREGAT } \\
\text { E(VMA) }\end{array}$ & $\begin{array}{c}\text { \% VOIDS } \\
\text { FILLED } \\
\text { WITH } \\
\text { BITUMEN } \\
\text { (VFB) }\end{array}$ \\
\hline 1 & 3 & 5 & 1050 & 3.10 & 2.24 & 3.86 & 15.04 & 74.12 \\
\hline 2 & 6 & 5 & 1120 & 3.88 & 2.25 & 3.43 & 14.66 & 76.23 \\
\hline 3 & 9 & 5 & 1185 & 3.91 & 2.25 & 3.21 & 14.48 & 77.18 \\
\hline
\end{tabular}

\subsection{Engineered Cementitious Composition}

Cement is the mixture of calcareous and argillaceous materials at a given proportions. Cement industry alone contributes $5 \%$ of the global carbon dioxide production. Cement production is growing by $2.5 \%$ annually and is expected to rise up to 4.4 billion tons by 2050(Madeleine, 2012).Due to the rising traffic in the world, the demand for concrete pavement roads has also magnified. This causes the use of more cement which is a danger to the natural ecosystem.

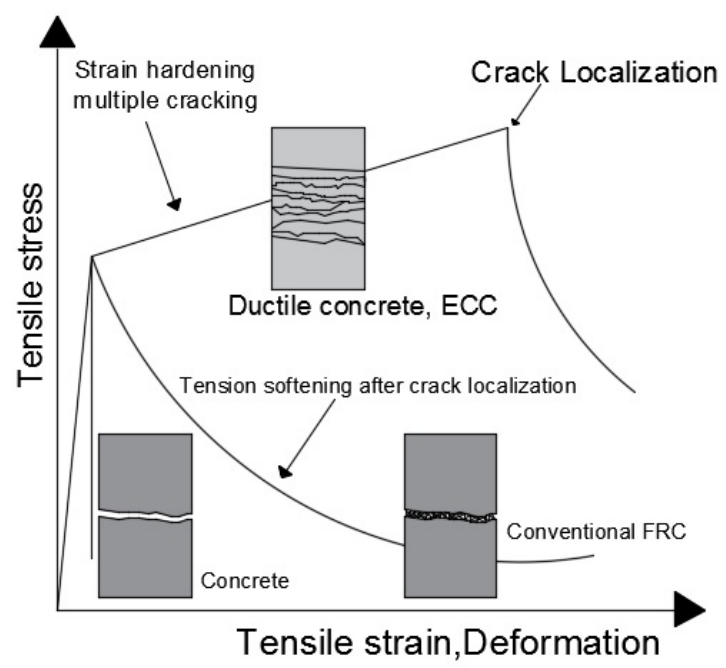

(a)

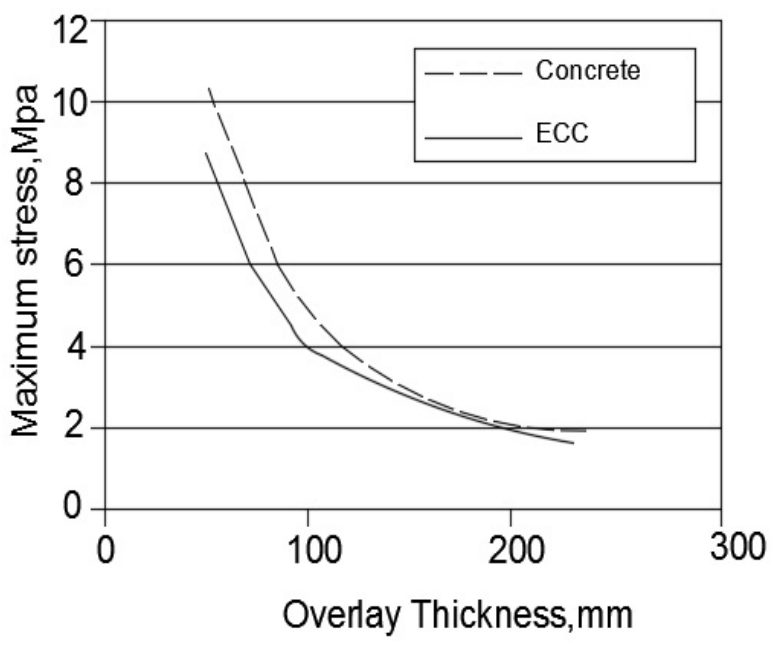

(b)

Figure 1. (a) Comparison of ECC material performance in uniaxial tension, (b) Design Chart for ECC and Concrete overlay thickness (Lepech, 2010)

Use of ECC (Engineered Cementitious Composition) has been a good effort to reduce the cement content in the construction of rigid pavement. ECC is a modified high-performance fiber reinforced cementitious compositions which have similar ductility as metals and has tight crack width. It has a strain capacity more than 300 times than ordinary concrete. Several tests, for example, mechanical loading, performance, shrinkage, permeability,abrasion,freeze-thaw,strength,environmental tests, etc has proved that ECC is a better than conventional cement compositions to use in highways. Use of ECC potentially can reduce about $70 \%$ use of virgin materials used for rigid pavements (Lepech, 2010). 


\subsection{Sustainable Rating Systems for Roadways}

\subsubsection{Green Roads}

A green road International is a nonprofit organization which has taken initiatives in devising suitable guidelines for making roads greener. A "Green road" is a transportation project that is designed and constructed to a level of sustainability substantially higher than current common practice. The GRI provided focuses on projects efficiently use resources and renewable materials; help reduces emissions, manage waste, enable multimodal transport. The organization has formulated guidelines for accessing the sustainability criteria of the road construction through studying life cycle analysis. This includes setting up indicators for materials used in construction. Some of the indicators are global warming potential, acidification, human health, resource depletion, etc. (Greenroads, 2016).

\subsubsection{Invest-(FWA)}

Infrastructure Voluntary Evaluation Sustainability Tool is a web-based self-evaluation tool comprised of voluntary sustainability best practices, called criteria, which cover the full lifecycle of transportation services, including system planning, project planning, design, and construction, and continuing through operations and maintenance. Federal Highway Administration's under US Department of Transportation developed this program for voluntary use by transportation agencies to analyze and elevate the sustainability of the projects.

INVEST criteria are basically divided into four modules (1) System Planning for States, (2) System Planning for Regions, (3) Project Development, (4) Operations and Maintenance. (Sustainablehighways, 2012).

\subsubsection{Green Lites}

Green LITES is a certification program developed by NYSDOT (New York State Department Of Transportation) in 2008. It is a self-certification program that distinguishes transportation projects and operations based on the extent to which they incorporate sustainable choices. This is basically an internal management program for NYSDOT to measure performance, recognize suitable practices, and identify zones for improvement. (New York State Department of Transportation, 2008).

There are other types of rating systems such as I-LAST :( Infrastructure Voluntary Evaluation Sustainability Tool) by (Illinois Department of Transportation, 2011), Green Guide for Roads: Alberta ,Green Pave: Ontario Ministry of Transportation ,Green Guide for Roads: Transportation Association of Canada and Envision, Institute of sustainable infrastructure (Asmar, 2013).

\section{Methodology}

The study investigation is cross-sectional in nature and not experimental. After studying the feasibility of the applications of alternative materials in road construction, data was collected about the properties of these materials. Data was collected from secondary resources, which included journal publications and company reviews. The data include information about the carbon footprint, embodied energy, recyclability, present tradition, and cost. The research used these data to compare the environmental properties and their impacts. The study aims to give a basic framework to analyze differences in using virgin materials over recycled industrial wastes in pavement design and construction. The industrial wastes such as scrap tires, glass and plastics were chosen. Furthermore, this research seeks to analyze these results and make an effort to claim the use of these materials over virgin materials in road design and construction. The study focuses on exploring the postulation of new materials for the substitution of traditional pavement materials aiming at the reduction and degradation of natural resources and enhancing the environmental sustainability.

\section{Results}

\subsection{Recycle Scrap Tires}

\subsubsection{Embodied Energy and Carbon Footprint}

Tire constitutes of rubber or elastomers, metals, textiles, additives, carbon-based materials and chemicals such as sulfur and zinc oxides. Steel cords run through the tire and other chemicals to make it more durable. The primary energy used is the burning of fossil fuels. Each year 6162 trillion Btu of energy is spent in processing steel and other alloys (Design lifecycle). After the acquisition of raw materials, they are shipped to the factories where the final product is created.--. Millions of tires are discarded every year which is toxic in nature. Although there are environmental laws, most of these tires end up in a landfill or are incinerated which is a hazard to the ecology.

This is an opportunity of recycling the tires to its maximum potential. It can be used in various industries especially in the construction environment. The use is promising and saves natural resources such as trees and asphalt. A study done at the University of Wisconsin proved that mechanical scrap tires can be used in the 
construction of pavements using various techniques(Eldin, 1992). The experiment used tested different pavements using various composition of scrap tires and soil and concluded that it is feasible to use tires in road construction with general maintenance. Considering recycling of these tires, they cannot be directly used. This requires proper recycling and converts them to final product for the road industry. ISRI (Institute of Scrap recycling Industries INC) measured the carbon footprint of recycling tires. The study was successful and it concluded that energy from recycled rubber has a lower carbon footprint than coal which is the main ingredient of energy production. The upstream carbon footprint for the production of asphalt is $840 \mathrm{~kg}$ of carbon dioxide equivalent per metric ton whereas it Is $124 \mathrm{~kg}$ of carbon dioxide equivalent to recycle tires per metric ton. When used in pavements, recycled rubber had between 3 and 7 times lower carbon footprint than asphalt (see figure 2).

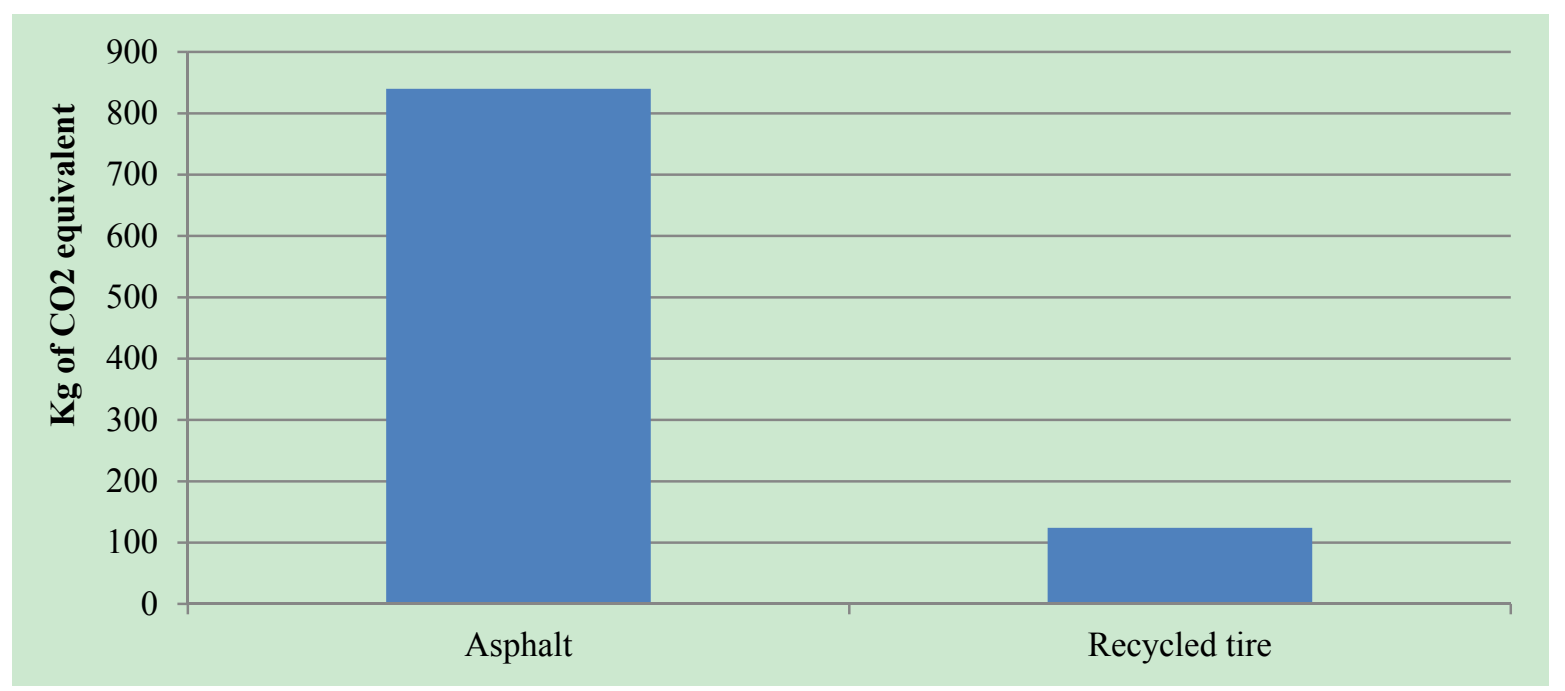

Figure 2. Difference in carbon dioxide equivalent between asphalt \& recycled tire, (ISRI,2009)

\subsubsection{Cost Analysis}

If we take an example of using tires in the pavement we can derive various forms of layer thickness. Taking into consideration a section from the study done at University of Wisconsin Department of transportation, we can get an approximate volume of tires used in one mile of road. From the figure, if we estimate for 1 mile of road, Approximate Volume of tires $=\left[3^{\prime} \times\left\{16.5^{\prime}+17^{\prime}\right\} / 2\right]$ x $\left.5280^{\prime}\right]($ (area of trapezium) which will be equal to 265,320 cubic feet of scrap tires.

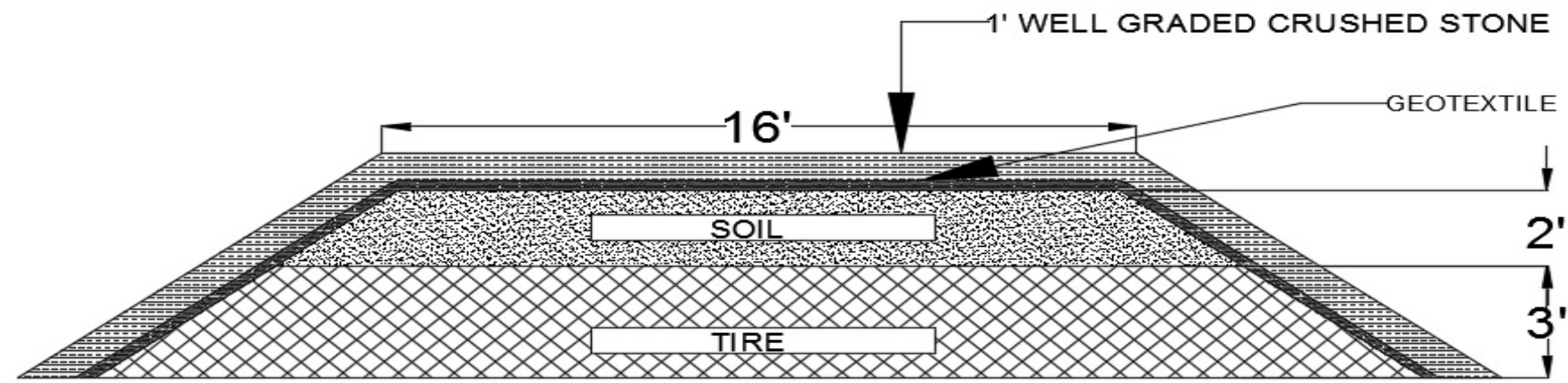

Figure 3. Section of pavement using scrap tires (Eldin, ASCE 1992)

Tire recycling is not a new business. Several firms focus on recycling tires into making the various products but it has not been on a massive scale. This emphasizes that there is a necessity of technological advancement in the recycling of these tires and diverting them into the construction industry. The cost of recycling will decrease when their new plants are installed which would cater to the demands.

Taking the case of Gainesville, Florida let us take a step in analyzing the approximate costs which are incurred in using traditional material over industrial wastes.

According to the department of Florida transportation, construction of a 2 lane asphalt roadway of one center 
mile will cost $\$ 7,321,444$ by LRE(Long Range Estimates). Some of the costs defined by Florida Department of Transportation (FDOT) as per 2013 are as follows:

Asphalt is projected around $100 \$$ per 1 ton,

Earthwork for $\$ 0.3$ per cubic feet and

Structural concrete (rigid pavements) to be $\$ 29.63$ per cubic feet.

Using the above pavement section using soil and scrap tires, it is estimated to have $265,320 \mathrm{ft}^{3}$ of tires which can be used as a replacement for 1 mile of road subgrade. Now the cost of the road section can be computed as

Compacted density of tires

$$
\begin{aligned}
& =40 \mathrm{lb} / \mathrm{ft}^{3} \\
& =40 \mathrm{lb} / \mathrm{ft}^{3} \times 265,320 \mathrm{ft}^{3} \\
& =10612800 \mathrm{lbs} \\
& =5306.4 \text { tons }(1 \text { ton }=2000 \mathrm{lbs})
\end{aligned}
$$

Comparing with the price of subbase and subgrade which mainly consists of aggregates and binder material, Density of coarse aggregate (crushed stone) and sand $=100 \mathrm{lb} / \mathrm{ft}^{3}$ (rfcafe, 2016).

Cost of aggregates $=\$ 30 /$ ton (Gravelshop,2016).

$\begin{array}{ll}\text { For } 265,320 \mathrm{ft}^{3} & =[\{(265,320 \times 100) / 2000)\} \times 30] \\ & =\$ 397,980 \\ \text { Volume of the } 1 \text { ' top course } & =33 \mathrm{ft}^{3} \\ \text { (Crushed stone) } & \\ \text { Cost of the top course } & =\$ 55\end{array}$

The hidden costs would be transporting the tires from the scrap tire factory to the recycling plant. In this case, it can be made sure the vehicles can be chosen which would run on sustainable fuels such as biodiesel and the recycling plant running on renewable energies. By spending $\$ 5000$ for a mile of road by replacing scrap tires, an amount of approximately $\$ 390,000$ can be saved.

1 tire barrel $=1$ ton which contains 100 tires wrapped together in a pile of $2.5 \times 4.5 \times 5$ feet.

5306.4 tons $=530640$ tires which can be purchased from Tallahassee for $\$ 0.7$ per barrel from a scrap tire company which equated to $\$ 3,714.48$ (USA scrap tire network, 2016). This is the amount of money a recycling plant can purchase for shredding and organizing. Then with a certain percentage of profit the company can sell the contractor for around \$5000.The hidden costs would be transporting the tires from the scrap tire factory to the recycling plant. In this case, it can be made sure the vehicles can be chosen which would run on sustainable fuels such as biodiesel and the recycling plant running on renewable energies. By spending $\$ 5,000$ for a mile of road taking this particular section, an equivalent amount of asphalt, fine aggregate and coarse aggregates which are very less expensive compared to traditional methods.

\subsection{Recycled Industrial Waste Glass}

The glass is a non-crystalline amorphous solid that is produced by supercooling of a mixture consisting silica sand $\left(\mathrm{SiO}_{2}\right)$ and soda ash (sodium carbonate) to a rigid state. This supercooled material does not crystallize and retains the internal structure. The other constituents of the material consist of sodium oxide $\left(\mathrm{Na}_{2} \mathrm{O}\right)$, lime $(\mathrm{CaO})$, and several minor additives. These are used in the forms of bulbs, cathode ray tubes, bottles, glasses and for packaging.

\subsubsection{Embodied Energy and Carbon Footprint}

Silica sand is the main ingredient which is mixed with lime and soda and is heated at around $1500{ }^{\circ} \mathrm{C}$ using fossil fuels. The molten glass is passed over molten tin at $1000^{\circ} \mathrm{C}$ and then cooled in a controlled manner to form a continuous sheet. This produces a substance known as Float glass whose thickness can range from $2-25 \mathrm{~mm}$. Several other additives are added like $\left(\mathrm{Mg}\right.$ and $\left.\mathrm{Al}_{2} \mathrm{O}_{3}\right)$ to help the melting process, and other oxides are added for color. The mining of silica sand which causes immense stress on the ecosystem. The embodied energy of glass is approximately $15.9 \mathrm{MJ} / \mathrm{Kg}$. (Andrew, 2010). Glass is $100 \%$ recyclable and can be recycled endlessly without any loss in purity or quality. Over a ton of natural resources are saved for every ton of glass recycled. The Energy costs drop about $2-3 \%$ for every $10 \%$ cullet used in the manufacturing process. 
The recycling of glass can be aggressively developed by using this in construction industries. The use of recycled glass in the pavement construction can drastically save energy as well as natural resources. When the waste glass is crushed to sand like particle sizes, similar to those of natural sand, it exhibits properties of an aggregate material. Glass has been proven as an effective fine aggregate and as an additive in the concrete. It can be applied in both flexible and rigid pavements. Materials such as glass have more than 100 years durability and remain unaffected by moisture content which is a required characteristic of good pavement. Studies have shown that use of recycled glass surges sound insulation.

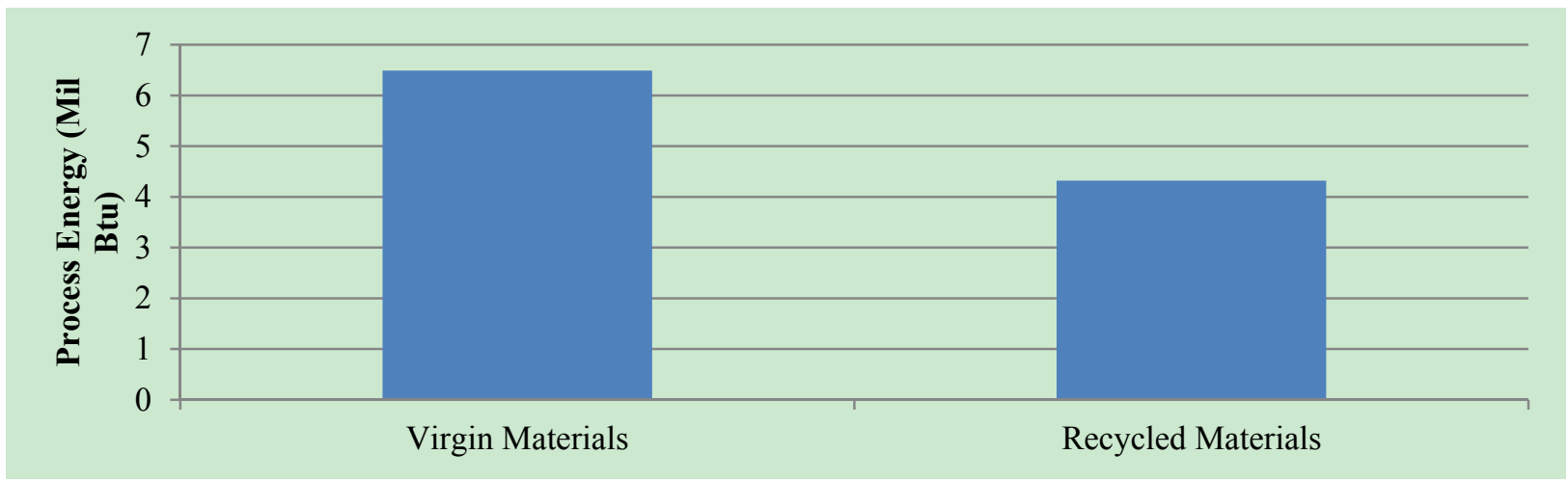

Figure 4. Comparison in process energy (Mil Btu) between virgin \& recycled materials, (EPA 2011)

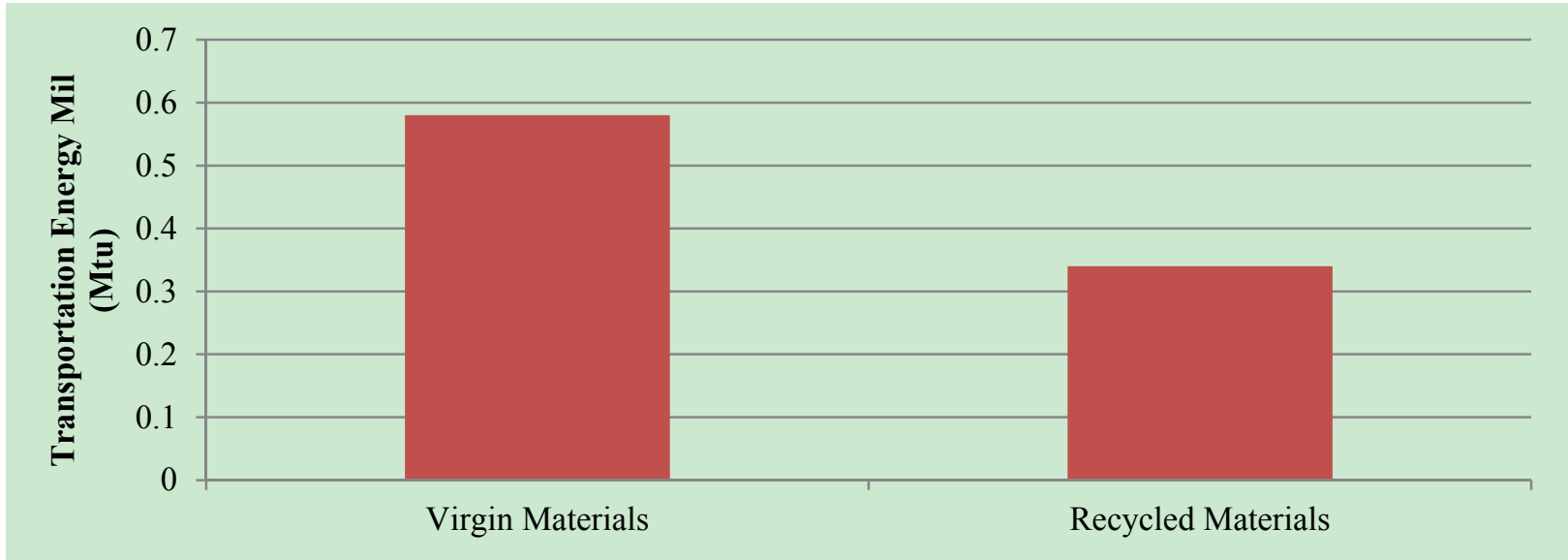

Figure 5. Comparison between virgin \& recycled materials in terms of transportation energy (Mil Btu), (EPA 2011)

\subsubsection{Cost Analysis}

Recycled waste glasses can be applied in both rigid and flexible pavements as replacements for aggregate. Assuming a rigid pavement, we can calculate the expenditure to replace the waste glass with concrete. Waste glass can be procured for $\$ 10$ a ton.(kdhnews,2013). According to a study at the University of Baghdad(2008), it is possible to replace $20 \%$ of the pavement with recycled glass without any changes of the strength and performance of the rigid pavement. Let us assume a rigid pavement using US standards in the southeast region of 8000psi which is M55.15806 M 55.16 grade concrete.

Table 5. Mix design of rigid pavement for 8000 psi (Athena Sustainable Materials Institute, 2014)

\begin{tabular}{lll}
\hline Compressive strength & psi & 8000 \\
\hline Portland cement & lbs & 900 \\
fly ash & lbs & 255 \\
Slag Cement & lbs & 44
\end{tabular}


Mixing Water

Crushed Coarse Aggregate

Natural Coarse Aggregate

Crushed Fine Aggregate

Natural Fine Aggregate

Air \%

Air Entraining Admixture

Water Reducer

High Range Water Reducer

accelerator

total weight lbs $\quad 350$

lbs $\quad 1133$

lbs 231

lbs 226

lbs $\quad 890$

oz $2 \%$

$\mathrm{OZ} \quad 0$

oz 3

oz 4

oz 10

lbs $\quad 4027$

Using this standard for 1 cubic yard of road, the materials are as follows,

Total amount of fine aggregates

$$
\begin{aligned}
& =890+226 \mathrm{lbs} \\
& =1116 \mathrm{lbs}
\end{aligned}
$$

$20 \%$ of this amount

$$
=223.2 \mathrm{lbs}
$$

For constructing in Gainesville, fine aggregate (sand) can be purchased at Alachua County for $\$ 30 /$ ton. (Gravelshop, 2016).

For $2000 \mathrm{lbs}$ the price of sand is $\$ 30 .(1 \mathrm{ton}=2000 \mathrm{lbs})$

For $223.3 \mathrm{lbs}=(30 / 2000) \times 223.2=\$ 3.35$

When we replace this amount by waste glass the prices are as follows,

1 ton $=\$ 10$

$$
223.2 \mathrm{lbs}=(10 / 2000) \times 223.2=\$ 1.12
$$

From above calculations, we can observe that the price of waste glass is $\$ 1.12$ for 223.2 lbs where the price of sand for the same amount is $\$ 3.35$.

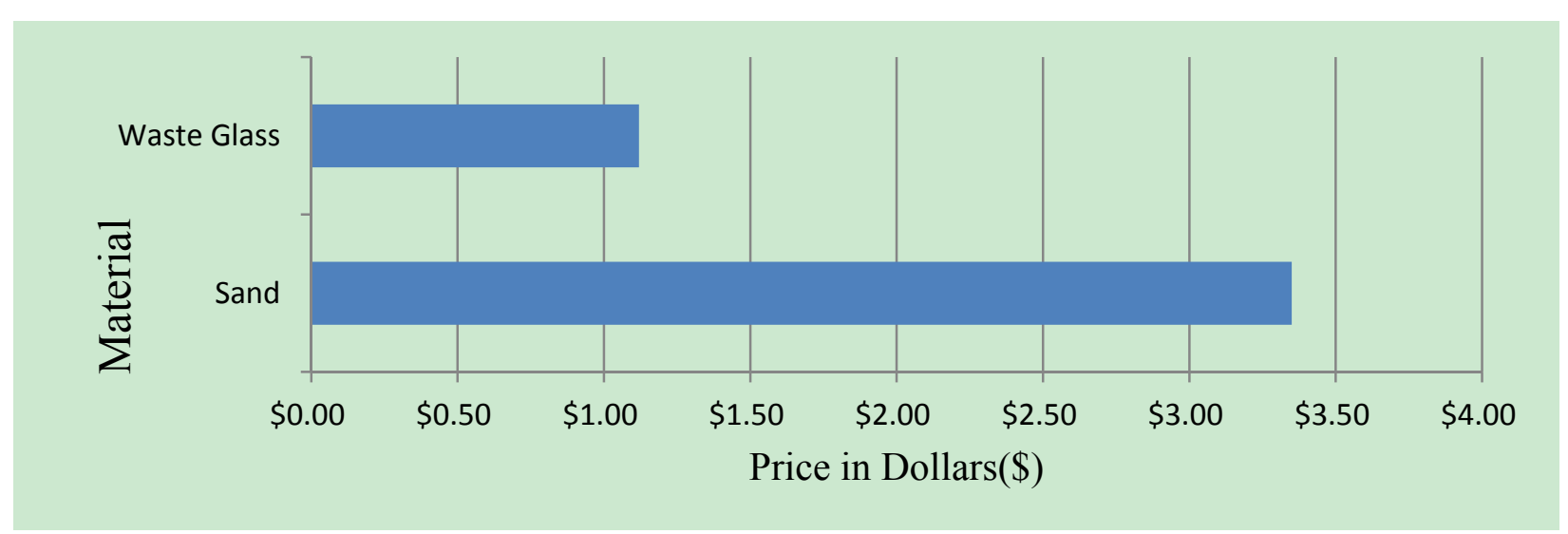

Figure 6. Price Difference in replacing sand with waste glass (Ashish, 2016)

\subsection{Industrial Recycled Plastics}

A plastic is a type of synthetic or man-made polymer; similar in many ways to natural resins found in trees and other plants. Webster's Dictionary defines polymers as any of various complex organic compounds produced by polymerization, capable of being molded, extruded, cast into various shapes and films, or drawn into filaments and then used as textile fibers. Plastic is one of the most important pollutants in the world contributing to climate change.

For more than 50 years, global production and consumption of plastics have continued to rise. An estimated 299 million tons of plastics were produced in 2013, representing a 4 percent increase over 2012, and confirming and 
upward trend over the past years. (World watch Institute - January 2015). According to a 2012 report by Global Industry Analysts, plastic consumption was to reach 297.5 million tons by the end of 2015 .

\subsubsection{Embodied Energy and Carbon Footprint}

The average embodied the energy of generating plastics is estimated at $90 \mathrm{MJ} / \mathrm{Kg}$. The carbon footprint of plastic (LDPE or PET, polyethylene) is about $6 \mathrm{~kg} \mathrm{CO} 2$ per $\mathrm{kg}$ of plastic. The production of $1 \mathrm{~kg}$ of polyethylene (PET or $\mathrm{LDPE}$ ) requires the equivalent of $2 \mathrm{~kg}$ of oil for energy and raw material. Polyethylene PE is the most commonly used plastic for plastic bags. Another study showed that burning $1 \mathrm{~kg}$ of oil creates about $3 \mathrm{~kg}$ of carbon dioxide). In other words: Per kg of plastic, about $6 \mathrm{~kg}$ carbon dioxide is created during production and incineration.

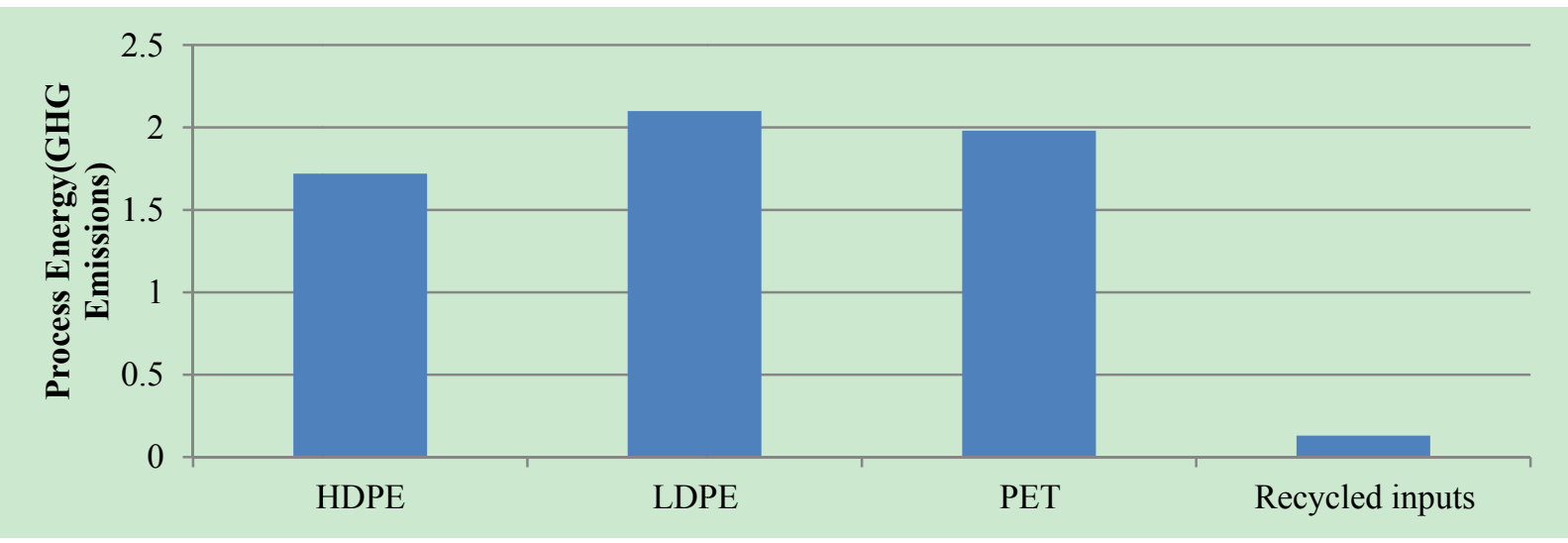

Figure 7. Difference in process energy in greenhouse gas emissions of virgin plastics and recycled plastics $\left(\mathrm{MTCO}_{2} \mathrm{E} / \mathrm{Ton}\right),(\mathrm{EPA}, 2009)$

Recycling of plastic saves on average about $2.5 \mathrm{~kg} \mathrm{CO}_{2}$ per $\mathrm{kg}$ of plastic. Thus recycled plastic produces about $3.5 \mathrm{~kg} \mathrm{CO}$ compared to $6 \mathrm{~kg}$ of $\mathrm{CO}_{2}$ for new plastic (production and incineration).About $6 \%$ of the worldwide oil consumption is used for the production of plastic (with increasing tendency). The use of waste plastics in road construction has been experimentally proved to be suitable in road industry and promises to the reduced use of bitumen or asphalt (Jafar,2015). The availability of waste plastics is abundant in the world but needs more technical plants to able to recycle for various applications.

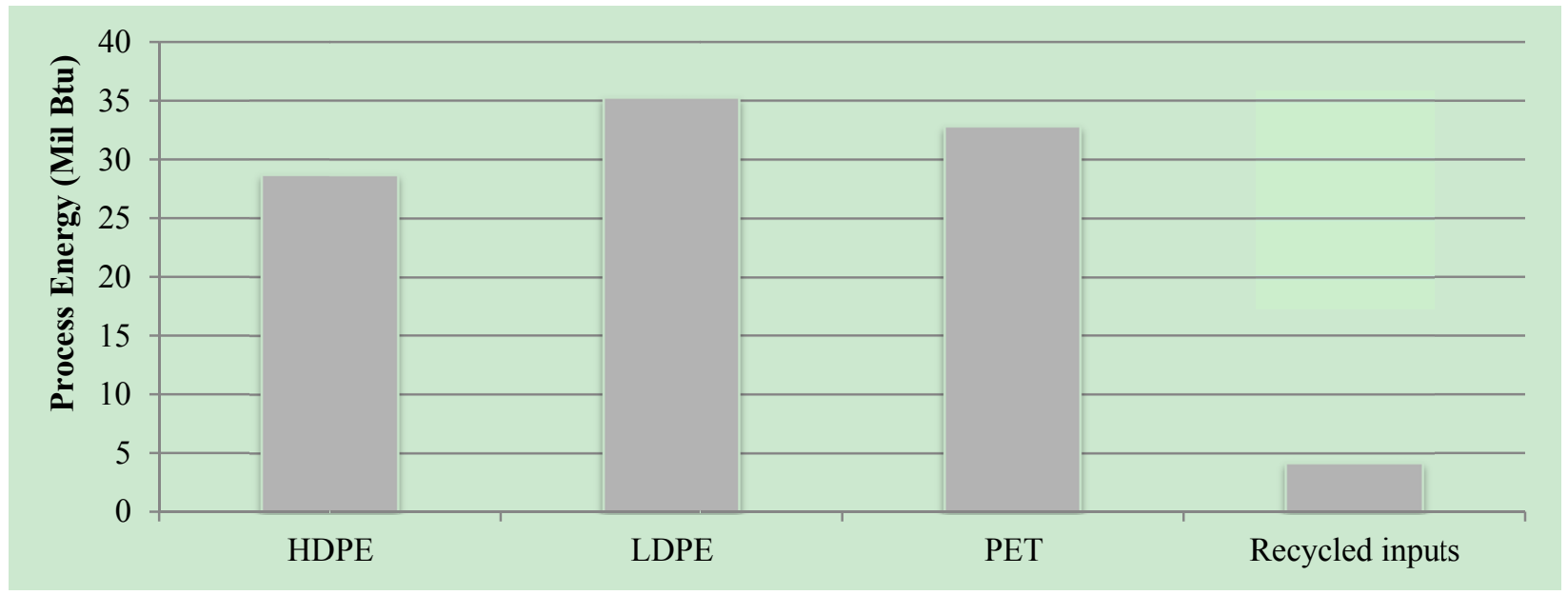

Figure 8. Difference in process energy of virgin plastics and recycled plastics, (EPA, 2009).

\subsubsection{Cost Analysis}

In the case of plastics, it can be used in two processes which are dry and wet processes. According to the study in $\mathrm{CET}(2012)$, it is possible to use around $15 \%$ of recycled plastic in a dry process and $8 \%$ in the wet process without any changes of the strength and performance of the bitumen.

Taking 1 mile of two-lane roadway, the amount of bitumen used is approximately 150 Metric Tons. 
$15 \%$ of this amount $=22.5$ Metric Tons of recycled plastics

$$
=49604 \mathrm{lbs} .(1 \mathrm{MT}=1000 \mathrm{~kg}, 1 \mathrm{~kg}=2.2 \mathrm{lbs})
$$

The total amount of recycled plastics can be purchased in the state of Florida for around $\$ 0.3$ per pound which equated to $\$ 14,881$ or the equivalent of $\$ 15,000$. By traditional means, the 22.5 Metric tons of pure bitumen costs approximately $\$ 3$ per gallon which results in a total amount of $\$ 19,677.312$. It proves that it is economically viable to use recycled plastics over pure nonrenewable fossil fuels.

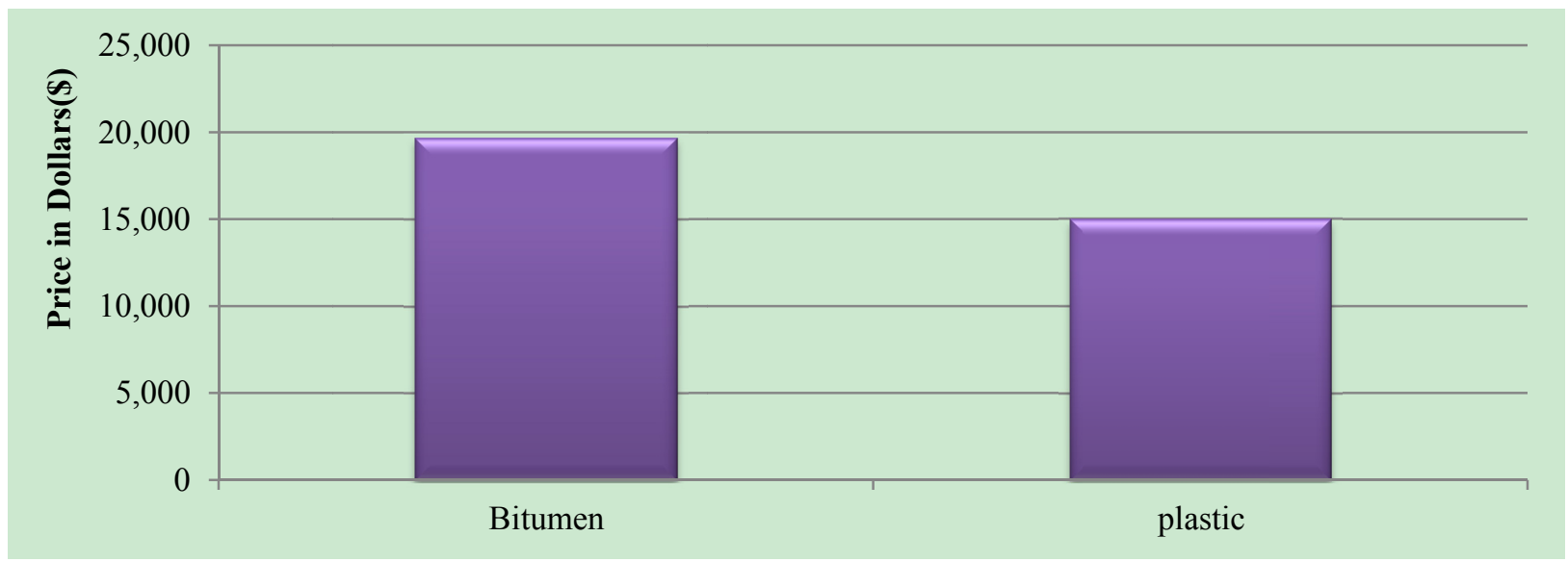

Figure 9. Energy savings per short ton of recycled material compared to landfilling, (WARM-13)

\section{Discussion}

There are several ways to construct the built environment and causing minimum damage to the environment. Sustainable transportation system is a step not only for environmental safety but also for human well-being and better economic stability.

Results from this study indicate that there are strong possibilities of achieving required standards for pavement construction using specific recycled industrial wastes such as glass, tires, plastics, asphalt, and ash. The major quantities of materials for pavement design are normally extracted from nonrenewable resources. Replacing these materials with renewable materials which are readily available will be a crucial step in building sustainable infrastructure. Furthermore, the amount of energy spent in (extraction, processing and transporting) application of traditional materials which is commonly known as embodied energy is significantly lower in using suggested alternate materials. In terms of economics, there can be significant benefits in adopting sustainable pavement design and construction process.

In the example given about constructed over 1 mile road in Gainesville, Florida using of recycled scrap tires results indicated that thousands of dollars could be saved. The amount of money which could be saved included the price of fine and coarse aggregates, binder materials, machinery and equipment, etc. Secondly, in using recycled plastics in flexible pavements over $\$ 4,600$ could be saved. And finally, in using recycled in a rigid pavement about $\$ 2.2$ could be saved for every cubic yard. In addition to the economic benefits, there are further benefits related to a social responsibility and maintaining healthy surrounding by reusing and recycling of materials in the construction of the built environment. Current challenges in adopting application of alternative materials in pavement design and construction include:

- Abundant and ready availability of traditional materials in the vicinity of any project site.

- The alternative materials such as recycled industrial waste are not available at convenient distances which make it difficult for their application.

- The matter of revising the use of traditional materials and considering the application of alternate materials and their benefits are not made aware at the local and regional scale.

- Imposition of stringent rules and regulations for introducing sustainability are not encouraged by the governing bodies.

- No compulsory guidelines on adopting any of green rating systems in all the projects (new construction, operation, maintenance and renovation). 
- Very limited research and development in innovation and experimentation of alternative materials in pavement performance.

- Lack of sufficient data on the engineering and strength parameters of the recycled industrial wastes in pavement applications.

- Lack of data on the feasibility of application of alternative replacement of traditional sources according to specific locations throughout the country.

- Under development in the area of efficient and greener off site construction (ex-Ready mix plants) for sustainable road materials.

The market came across an invention in 2014, when a startup company by Scott and Julie Brusaw who invented "Solar Roadways" which was an effort to generate electricity as well as solve the transportation problem. The pavement sections were made by hexagonal panels with specific wattage and LED integrated into it. The roads are designed to collect the maximum solar energy which would hit the surface and serve a dual purpose: modern infrastructure and smarter grid.

\section{Conclusion}

One of the key challenges facing infrastructure construction is spreading awareness of the necessity for a shift in design and construction of transportation systems. Using traditional materials for road construction has many negative economic impacts and contributes to ecological imbalance. There are needs for new guidelines that are compatible and consistent with the alternative sustainable materials and methods of construction. This study aimed at investigating alternate sustainable materials for road construction and determines factors that depict environmental advantages of using these alternate materials. When comparing parameters such as embodied energy, the study showed that using industrial waste materials (recycled tires, glass, and plastic) in road construction does have less expenditure in energy and is environmentally safe.

The outcomes of this study provide basic principles to encourage respective authorities to design and construct roadways using recycled industrial wastes in developing countries and emerging economies such as India, Brazil, China and other such countries. These research results aim to promote sustainable transportation infrastructures to advance prosperous economic development around the world.

\section{References}

Alcorn, A. (2010). Global Sustainability and the New Zealand House, a thesis submitted to Victoria University of Wellington.

Awwad, M. T., \& Shbeeb, L. (2007). The use of polyethylene in hot asphalt mixtures. American Journal of Applied Sciences, 4(6), 390-396. https://doi.org/10.3844/ajassp.2007.390.396

Behl, A., Sharma, G., \& Kumar, G. (2014). A sustainable approach: Utilization of waste PVC in asphalting of roads. Construction and Building Materials, 54,113-117. https://doi.org/10.1016/j.conbuildmat.2013.12.050

Bharadwaj, A. (2010, May 16). Eco-friendly plastic roads in Himachal Pradesh. Retrieved from http://www.dnaindia.com/india/report-eco-friendly-plastic-roads-in-himachal-pradesh-1383591

Consoli, N. C., Montardo, J. P., Prietto, P. D. M., \& Pasa, G. S. (2002). Engineering behavior of a sand reinforced with plastic waste. Journal of Geotechnical and Geoenvironmental Engineering, 128(6), 462-472. https://doi.org/10.1061/(ASCE)1090-0241(2002)128:6(462)

Density of common building materials. (2016). Retrieved from http://www.rfcafe.com/references/general/density-building-materials.htm

Disfani, M. M., Arulrajah, A., Bo, M. W., \& Hankour, R. (2011). Recycled crushed glass in road work applications. Waste Management, 31(11), 2341-2351. https://doi.org/10.1016/j.wasman.2011.07.003

Eldin, N. N., \& Senouci, A. B. (1992). Use of scrap tires in road construction. Journal of Construction Engineering and Management, 118(3), 561-576. https://doi.org/10.1061/(ASCE)0733-9364(1992)118:3(561)

Engineering properties of tire bales, Encore Systems Inc., TDOT (Texas Department Of Transportation). Retrieved from ftp://ftp.dot.state.tx.us/pub/txdot-info/gsd/pdf/stbguide.pdf

Fuel and bituminous price index, Florida Department of Transportation. (2014). Retrived from http://www.dot.state.fl.us/construction/fuel\&bit/fuel\&bit.shtm

Gawande, A., Zamare, G., Renge, V. C., Tayde, S., \& Bharsakale, G. (2012). An overview on waste plastic 
utilization in asphalting of roads. Journal of Engineering Research and Studies, 3(2), 1-5.

Green LITES. (2008). New York Department of Transportation. Retrieved from https://www.dot.ny.gov/programs/greenlites

Huang, Y., Bird, R. N., \& Heidrich, O. (2007). A review of the use of recycled solid waste materials in asphalt $\begin{array}{llll}\text { pavements. Resources, } \quad \text { Conservation and } & \text { 52(1), }\end{array}$ https://doi.org/10.1016/j.resconrec.2007.02.002

INVEST (Infrastructure Voluntary Evaluation Sustainability Tool). (2012). US Department of Transportation(Federal Highway Administration). Retrieved from https://www.sustainablehighways.org/

IRC (SP)-58, Guidelines for Use of Fly Ash in Road Embankments, Indian Roads Congress. Retrieved from https://law.resource.org/pub/in/bis/irc/irc.gov.in.sp.058.1999.pdf

Ismail, Z. Z., \& Al-Hashmi, E. A. (2009). Recycling of waste glass as a partial replacement for fine aggregate in concrete. Waste management, 29(2), 655-659. https://doi.org/10.1016/j.wasman.2008.08.012

Jafar, J. J. (2016). Utilization of waste plastic in the bituminous mix for improved performance of roads. KSCE Journal of Civil Engineering, 20(1), 243-249. https://doi.org/10.1007/s12205-015-0511-0

Lepech, M. D., \& Li, V. C. (2010). Sustainable pavement overlays using engineered cementitious composites. International Journal of Pavement Research and Technology, 3(5), 241.

Milne, G. (2013). Embodied energy, Yourhome (Australia's guide to environmentally sustainable homes). Retrieved from http://www.yourhome.gov.au/materials/embodied-energy

Owen, K. C. (1999). Scrap tires: a pricing strategy for a recycling industry. Corporate environmental strategy, 5(2), 42-50. https://doi.org/10.1016/S1066-7938(00)80065-2

PET recycling Recycler's Exchange Index. (2016). Retrieved from http://www.recycle.net/Plastic/PET/xv100100.html

Plastics Recycling, North American Plastic Recycling Network. (2016). Retrieved from http://www.recyclingplasticwaste.com/cgibin/rexview.cgi?rex $=000083 \& w s c=13-0507$

Price of crushed stone. (2016). Barrestone. Retrieved from http://www.barrestone.com/price.asp

Price of crushed stone. (2016). Improvenet. Retrieved from $\mathrm{http} / / / \mathrm{www}$.improvenet.com/r/costs-and-prices/crushed-stone

Prices of recycled glass, Is recycling glass worth the cost?, Brandon Janes. (June 20). Retrieved from http://kdhnews.com/news/is-recycling-glass-worth-the-cost/article_8e2dd0e6-d956-11e2-ab95-0019bb30f3 1a.html

Prices of recycled tires, Scrap Tire Disposal and Recycling. (2016). Retrieved from http://www.recycle.net/

Prices of recycled tires, USA scrap tire network. (2016). Retrieved from http://www.scraptire.net/cgi-bin/rexview.cgi?rex $=000245 \&$ wsc $=01-1301$

Prices of sand. (2016). Alachua county prices. Retrieved from http://www.gravelshop.com/florida-48/alachua-county-799/32603-gainesville/

Rebeiz, K. S., \& Craft, A. P. (1995). Plastic waste management in construction: technological and institutional $\begin{array}{lllll}\text { issues. } & \text { Resources, } & \text { conservation and recycling, }\end{array}$ https://doi.org/10.1016/0921-3449(95)00034-8

Recycling, Florida Department of environmental protection. (2016). Retrieved from http://www.dep.state.fl.us/waste/categories/recycling/

Rokade, S. (2012). Use of waste plastic and waste rubber tires in flexible highway pavements. In International conference on future environment and energy, IPCBEE (Vol. 28).

Saride, S., Avirneni, D., \& Javvadi, S. C. P. (2015). Utilization of reclaimed asphalt pavements in Indian low-volume roads. Journal of Materials in Civil Engineering.

Shayan, A., \& Xu, A. (2004). Value-added utilization of waste glass in concrete. Cement and concrete research, 34(1), 81-89. https://doi.org/10.1016/S0008-8846(03)00251-5

Solar roadways, Kathy Wilson Peacock. (2010). Retrieved from http://resources.gale.com/gettingtogreenr/current-issues/solar-roadways-wave-of-the-future-or-money-sucki ng-vortex/ 
Swami, V., Jirge, A., Patil, K., Patil, S., Patil, S., \& Salokhe, K. (2012). Use of waste plastic in the construction of the bituminous road. International Journal of Engineering Science and Technology, 4(5), 2351-2351.

Swearingen, D. L., Jackson, N. C., \& Anderson, K. W. (1992). Use of Recycled materials in highway construction. Retrieved from http://www.wsdot.wa.gov/research/reports/fullreports/252.1.pdf

What is a carbon footprint - definition. (2016). Retrieved from http://timeforchange.org/what-is-a-carbon-footprint definition

Williams, A. S. (2009). Life cycle analysis: A step by step approach. Champaign, IL: Illinois Sustainable Technology Center.

\section{Copyrights}

Copyright for this article is retained by the author(s), with first publication rights granted to the journal.

This is an open-access article distributed under the terms and conditions of the Creative Commons Attribution license (http://creativecommons.org/licenses/by/4.0/). 